\title{
DIFFERENCES IN YIELD OF DIPLOID AND TETRAPLOID RED CLOVER IN LITHUANIA
}

\author{
Žilvinas Liatukas and Jovita Bukauskaitè \\ Lithuanian Research Centre for Agriculture and Forestry, Institute of Agriculture, \\ Instituto av. 1, LT-58344, Akademija, Kèdainiai distr., LITHUANIA; \\ jovita.bukauskaite@|zi.It
}

Communicated by Isaak Rashal

\begin{abstract}
The research was carried out in 2003-2011 at the Institute of Agriculture, Lithuanian Research Centre for Agriculture and Forestry. The fresh forage, dry matter (DM) and seed yields of red clover diploid and tetraploid populations and cultivars were determined. In total 58 diploids and 35 tetraploids were evaluated during four cycles in the study period. The average DM yield of diploids was $16.6 \mathrm{tha}^{-1}$ and of tetraploids was $17.8 \mathrm{tha}^{-1}$. The tetraploid average DM yield surpassed that of diploids by only $6.5 \%$. The seed yield was very low over the period. The average seed yield of diploids was $110.4 \mathrm{~kg} \mathrm{ha}^{-1}$. The average seed yield of tetraploids was $94.9 \mathrm{~kg} \mathrm{ha}^{-1}$. The diploid average seed yield was higher than that of tetraploids by $16.3 \%$. The highest negative impact on seed yield was due to wet weather in the seed harvest year, which was favourable for development of diseases on above-ground plant parts. The study showed that tetraploid red clover had no significant advantage over diploid red clover in DM yield under Lithuanian conditions. Variation in seed yield showed that production of diploid red clover seed is less problematic. It seems that only directed disease resistance breeding can improve seed yield as well as forage yield of red clover.
\end{abstract}

Key words: Trifolium pratense, grass, dry matter, seed yield.

\section{INTRODUCTION}

Red clover (Trifolium pratense L.) is widely grown in the temperate climate zone as a forage legume. Red clover is adapted to a wide range of soil types and fertility, climatic conditions and land-use patterns. It is an excellent nitrogen source, and a couple of centuries ago it was the main nitrogen source in Europe (Taylor, 2008). The yield potential of some genotypes exceeds that of non-improved lucerne cultivars. It possesses superior forage quality. However, its present area has highly decreased compared to the area before 50-60 years. One of the main factors for this was low nitrogen fertilisers cost at the end of $20^{\text {th }}$ century (Taylor and Quesenberry, 1996). On the other hand, in Europe there have been many efforts to develop sustainable and environmentally friendly agriculture. Therefore, farmers have a more positive attitude to use of red clover in crop rotations at present (Helgadottir et al., 2000; Black et al., 2009; Tavlas, 2009; Zuk-Golaszewska et al., 2010). Organic farming has become popular, and productivity in crop rotations of this system is highly dependent on red clover. Red clover as a catch crop is one of the most yielding among forage crops (Marcinkevičienè and Bogužas, 2011). However, relative high seed price does not make this plant very attractive for such use.
Although the red clover growing area has declined, breeding efforts have not been suspended. As a result, red clover cultivars with higher yield, better persistence due to improved disease resistance are available. Both di- and tetraploid forms are widely available to growers (Anonymous, 2009). The tetraploid form was developed, as it was considered that a higher ploidity level should increase yield. The majority of investigations have shown that tetraploid cultivars are more productive in forage and dry matter yield than diploid cultivars. However, many researchers have noted generally lower seed yield in tetraploid cultivars (Muntean and Savati, 2003; Drobna, 2009; Onal, 2011). Cultivars of both ploidy forms are registered in Lithuania. Nine cultivars of red clover with different earliness and disease resistance have been bred. Eight cultivars have been registered, of which five are diploid and three are tetraploid forms.

The aim of the present work was comparison of forage dry matter and seed yield of red clover di- and tetraploid genotypes under Lithuanian conditions.

\section{MATERIAL AND METHODS}

The study was carried out at the Institute of Agriculture, Lithuanian Research Centre for Agriculture and Forestry in 
a field utilizing a six-year crop rotation of forage crops in during 2003-2011. The soil of the experimental site was a Endocalcari-Endohypogleyic Cambisol CMg-n-w-can ( $\mathrm{pH}$ $7.2-7.3, \mathrm{P}_{2} \mathrm{O}_{5} 201-270 \mathrm{mg} \mathrm{kg}^{-1}$ and $\mathrm{K}_{2} \mathrm{O} 101-175 \mathrm{mg} \mathrm{kg}^{-1}$, humus $2.0-2.46 \%$ ). Red clover was sown after black fallow without a cover crop in July. Fertilizers $\mathrm{P}_{60} \mathrm{~K}_{90}$ were applied before sowing once. Breeding nurseries and cultivar testing trials of perennial legumes were used for two years. The plots were sprayed with herbicide (Basagran 480, 2 $1 \mathrm{ha}^{-1}$ ) when red clover developed the first true leaf in a sowing year. All genotypes were sown in $17 \mathrm{~m}^{2}(10 \times 1.7$ $\mathrm{m})$ plots in three replications by a special sowing machine Hege 80 at seed rate $10 \mathrm{~kg} \mathrm{ha}^{-1}$. In total, 58 diploid and 35 tetraploid cultivars and populations were evaluated during four cycles of the study period. The first cycle was started in 2003 and was evaluated in 2004-2005. The second cycle started in 2005 and was evaluated in 2006-2007. The further cycles followed this pattern. Nurseries were established in the first growth year. Forage and seed yield was evaluated in the second year and only forage yield was evaluated in the third year. Harvest was made three times per year. Forage was harvested at the same growth stage each year at the beginning of flowering. Dry matter (DM) yield was calculated from total forage yield using fresh plant samples of $500 \mathrm{~g}$ weight. The obtained forage and DM yield were recalculated to $\mathrm{t} \mathrm{ha}^{-1}$. Seed yield was recalculated to $\mathrm{kg} \mathrm{ha}^{-1}$.

The testing period included years with very different weather conditions, characterised as follows:

2003: dry and hot summer, germination was uneven, plants finished germination in September; rather cold and dry autumn;

2004: medium cold winter, low snow cover, dry spring, wet summer, normal autumn, warm December;

2005: warm January and cold February, normal spring, red clover crop was heavily damaged by Sclerotinia trifoliorum and Fusarium spp., warm summer, very warm and dry autumn;

2006: cold winter with medium snow cover, dry spring, dry and hot summer, warm autumn;

2007: winter with short cold period, normal spring, summer and autumn;

2008: very warm winter, rather dry spring and first part of summer, normal autumn;

2009: warm winter, normal spring, wet summer; normal autumn;

2010: very hard winter, normal spring, wet and hot summer, normal autumn;

2011: hard winter with very heavy snow, red clover crop was heavily damaged by $S$. trifoliorum and Fusarium spp., cold first part of spring, dry and hot May and June, wet in remaining part of summer (data from the Dotnuva Weather Station).
The data were processed by means of ANOVA statistical analysis.

\section{RESULTS}

The average red clover diploid and tetraploid fresh forage and DM yield were lowest in the 2003 sowing year and highest in the 2007 sowing year (Table 1). Forage and DM yield of red clover tetraploid genotypes was slightly higher compared with that of diploid genotypes (Tables 1-4). Differences in forage yield were higher than those in DM yield. The average forage yield of tetraploid red clover was higher compared with that of diploid clover by $12.3 \%$. The average DM yield of tetraploid red clover compared with that of the diploids was higher only by $6.5 \%$.

Table 1

STATISTICAL CHARACTERISTICS OF DIPLOID AND TETRAPLOID GENOTYPE FORAGE AND DRY MATTER YIELD

\begin{tabular}{l|c|c|c|c|c|c|c|c}
\hline \multirow{2}{*}{ Statistics } & Grass & DM & Grass & DM & Grass & DM & Grass & DM \\
\cline { 2 - 9 } & \multicolumn{2}{|c}{2003} & \multicolumn{2}{c}{2005} & \multicolumn{2}{c}{2007} & \multicolumn{2}{c}{2009} \\
\hline Average & 10.28 & 2.43 & 13.04 & 3.11 & 16.08 & 3.31 & 14.9 & 3.16 \\
Variance & 27.7 & 5.26 & 23.5 & 1.34 & 28.5 & 2.07 & 29.7 & 6.06 \\
Standard & 5.26 & 2.29 & 4.85 & 1.16 & 5.34 & 1.43 & 7.06 & 2.50 \\
deviation & & & & & & & & \\
Minimum & 1.2 & 0.26 & 4.3 & 0.94 & 6.4 & 0.8 & 4.95 & 0.37 \\
Maximum & 21.6 & 27.67 & 27.4 & 7.02 & 33.6 & 7.5 & 41.3 & 19.36 \\
$\begin{array}{l}\text { Coefficient } \\
\text { of variation }\end{array}$ & 51.1 & 94.4 & 37.2 & 37.3 & 33.2 & 43.5 & 52.8 & 58.9
\end{tabular}

Table 2

RED CLOVER DIPLOID AND TETRAPLOID GENOTYPE FORAGE AND DRY MATTER YIELD IN 2004 AND 2005, SOWING YEAR 2003

\begin{tabular}{|c|c|c|c|c|c|c|c|}
\hline Ploidy & $\mathrm{I}$ & $\mathrm{CV}, \%$ & II & $\mathrm{CV}, \%$ & III & $\mathrm{CV}, \%$ & Total \\
\hline \multicolumn{8}{|c|}{2004} \\
\hline & \multicolumn{7}{|c|}{ Grass yield, $\mathrm{t} \mathrm{ha}^{-1}$} \\
\hline Diploid, $* \mathrm{n}=12$ & 14.77 & 20.03 & 12.94 & 16.55 & 5.23 & 32.1 & 32.91 \\
\hline Tetraploid, $\mathrm{n}=6$ & 17.65 & 9.57 & 16.47 & 10.04 & 7.06 & 13.60 & 41.18 \\
\hline \multirow[t]{2}{*}{$\mathrm{R}_{05}$} & 0.917 & & 1.569 & & 0.806 & & \\
\hline & \multicolumn{7}{|c|}{ Dry matter yield, $\mathrm{t} \mathrm{ha}^{-1}$} \\
\hline Diploid, $\mathrm{n}=12$ & 4.63 & 12.16 & 3.38 & 10.61 & 2.00 & 24.94 & 10.01 \\
\hline Tetraploid, $\mathrm{n}=6$ & 5.10 & 9.66 & 4.12 & 10.08 & 2.37 & 12.66 & 11.59 \\
\hline \multirow[t]{3}{*}{$\mathrm{R}_{05}$} & 0.528 & & 0.634 & & 0.451 & & \\
\hline & \multicolumn{7}{|c|}{2005} \\
\hline & \multicolumn{7}{|c|}{ Grass yield, $\mathrm{t} \mathrm{ha}^{-1}$} \\
\hline Diploid, $n=12$ & 12.94 & 14.36 & 7.65 & 20.58 & 1.88 & 25.26 & 22.47 \\
\hline Tetraploid, $\mathrm{n}=6$ & 11.77 & 13.96 & 9.71 & 11.04 & 2.47 & 17.12 & 23.95 \\
\hline \multirow[t]{2}{*}{$\mathrm{R}_{05}$} & 0.810 & & 0.515 & & 0.223 & & \\
\hline & \multicolumn{7}{|c|}{ Dry matter yield, $\mathrm{t} \mathrm{ha}^{-1}$} \\
\hline Diploid, $\mathrm{n}=12$ & 3.06 & 11.47 & 1.91 & 15.15 & 0.45 & 18.79 & 5.42 \\
\hline Tetraploid, $\mathrm{n}=6$ & 2.47 & 13.24 & 2.33 & 7.06 & 0.54 & 14.7 & 5.34 \\
\hline $\mathrm{R}_{05}$ & 0.222 & & 0.341 & & 0.060 & & \\
\hline
\end{tabular}

*n, number of varieties and populations 
RED CLOVER DIPLOID AND TETRAPLOID GENOTYPE FORAGE AND DRY MATTER YIELD IN 2006 AND 2007, SOWING YEAR 2005

\begin{tabular}{|c|c|c|c|c|c|c|c|}
\hline Ploidy & I & $\mathrm{CV}, \%$ & II & $\mathrm{CV}, \%$ & III & $\mathrm{CV}, \%$ & Total \\
\hline \multicolumn{8}{|c|}{2006} \\
\hline \multicolumn{8}{|c|}{ Grass yield, $\mathrm{t} \mathrm{ha}^{-1}$} \\
\hline Diploid, $* \mathrm{n}=18$ & 16.88 & 21.96 & 12.90 & 15.42 & - & - & 27.78 \\
\hline Tetraploid, $\mathrm{n}=11$ & 22.39 & 9.20 & 11.78 & 11.81 & - & - & 34.17 \\
\hline $\mathrm{R}_{05}$ & 0.799 & & 0.567 & & & & \\
\hline \multicolumn{8}{|c|}{ Dry matter yield, $\mathrm{t} \mathrm{ha}^{-1}$} \\
\hline Diploid, $\mathrm{n}=18$ & 4.45 & 16.56 & 4.69 & 11.89 & - & - & 9.14 \\
\hline Tetraploid, $\mathrm{n}=11$ & 5.76 & 10.47 & 3.68 & 9.17 & - & - & 9.44 \\
\hline \multirow[t]{3}{*}{$\mathrm{R}_{05}$} & 0.249 & & 1.694 & & & & \\
\hline & 2007 & & & & & & \\
\hline & Grass yi & eld, tha & & & & & \\
\hline Diploid, $\mathrm{n}=18$ & 17.49 & 17.10 & 13.88 & 26.50 & 9.70 & 12.08 & 41.07 \\
\hline Tetraploid, $\mathrm{n}=11$ & 20.21 & 11.30 & 12.57 & 20.87 & 11.19 & 8.61 & 43.97 \\
\hline \multirow{2}{*}{$\mathrm{R}_{05}$} & 1.262 & & 1.193 & & 0.551 & & \\
\hline & Dry mat & ter yield & $\mathrm{tha}^{-1}$ & & & & \\
\hline Diploid, $\mathrm{n}=18$ & 3.88 & 11.00 & 3.19 & 14.38 & 1.96 & 8.48 & 9.03 \\
\hline Tetraploid, $\mathrm{n}=11$ & 4.48 & 10.41 & 2.94 & 12.00 & 2.09 & 4.91 & 9.51 \\
\hline $\mathrm{R}_{05}$ & 0.361 & & 0.344 & & 0.110 & & \\
\hline
\end{tabular}

$*_{n}$, number of varieties and populations

Table 4

RED CLOVER DIPLOID AND TETRAPLOID GENOTYPE FORAGE AND DRY MATTER YIELD IN 2008 AND 2009, SOWING YEAR 2007

\begin{tabular}{|c|c|c|c|c|c|c|c|}
\hline Ploidy & I & $\mathrm{CV}, \%$ & II & $\mathrm{CV}, \%$ & III & $\mathrm{CV}, \%$ & Total \\
\hline \multicolumn{8}{|c|}{2008} \\
\hline & \multicolumn{7}{|c|}{ Grass yield, $\mathrm{t} \mathrm{ha}^{-1}$} \\
\hline Diploid, $* \mathrm{n}=14$ & 21.77 & 13.80 & 15.82 & 21.42 & 9.57 & 8.77 & 47.16 \\
\hline Tetraploid, $\mathrm{n}=7$ & 24.02 & 18.26 & 17.42 & 19.80 & 10.20 & 11.37 & 51.64 \\
\hline \multirow[t]{2}{*}{$\mathrm{R}_{05}$} & 1.663 & & 1.512 & & 0.441 & & \\
\hline & \multicolumn{7}{|c|}{ Dry matter yield, $\mathrm{t} \mathrm{ha}^{-1}$} \\
\hline Diploid, $\mathrm{n}=14$ & 5.11 & 7.71 & 3.16 & 11.50 & 2.08 & 9.73 & 10.35 \\
\hline Tetraploid, $\mathrm{n}=7$ & 5.37 & 10.78 & 2.76 & 10.47 & 2.08 & 7.84 & 10.21 \\
\hline \multirow[t]{3}{*}{$\mathrm{R}_{05}$} & 0.359 & & 0.767 & & 0.105 & & \\
\hline & \multicolumn{7}{|l|}{2009} \\
\hline & \multicolumn{7}{|c|}{ Grass yield, $\mathrm{t} \mathrm{ha}^{-1}$} \\
\hline Diploid, $\mathrm{n}=14$ & 19.48 & 23.71 & 11.91 & 22.57 & 16.20 & 10.91 & 47.59 \\
\hline Tetraploid, $\mathrm{n}=7$ & 20.58 & 13.67 & 14.01 & 17.06 & 17.41 & 11.17 & 52.00 \\
\hline \multirow[t]{2}{*}{$\mathrm{R}_{05}$} & 1.565 & & 1.193 & & 0.834 & & \\
\hline & \multicolumn{7}{|c|}{ Dry matter yield, $\mathrm{t} \mathrm{ha}^{-1}$} \\
\hline Diploid, $\mathrm{n}=14$ & 4.69 & 13.80 & 1.50 & 14.85 & 3.59 & 6.25 & 9.78 \\
\hline Tetraploid, $\mathrm{n}=7$ & 4.93 & 8.94 & 1.75 & 9.95 & 3.66 & 8.62 & 10.34 \\
\hline $\mathrm{R}_{05}$ & 0.325 & & 0.147 & & 0.186 & & \\
\hline
\end{tabular}

$*_{\mathrm{n}}$, number of varieties and populations

Weather had high impact on yield of both red clover ploidy types. The nurseries of the sowing year 2005 and 2007 yielded very similarly in both years in 2006-2007 and in
RED CLOVER DIPLOID AND TETRAPLOID GENOTYPE FORAGE AND DRY MATTER YIELD IN 2010 AND 2011, SOWING YEAR 2009

\begin{tabular}{|c|c|c|c|c|c|c|c|}
\hline Ploidy & I & $\mathrm{CV}, \%$ & II & $\mathrm{CV}, \%$ & III & $\mathrm{CV}, \%$ & Total \\
\hline & \multicolumn{7}{|l|}{2010} \\
\hline & \multicolumn{7}{|c|}{ Grass yield, $\mathrm{t} \mathrm{ha}^{-1}$} \\
\hline Diploid, $* \mathrm{n}=12$ & 25.00 & 16.69 & 8.18 & 38.05 & 9.35 & 26.37 & 42.53 \\
\hline Tetraploid, $\mathrm{n}=6$ & 28.95 & 19.66 & 10.53 & 24.82 & 11.00 & 21.41 & 50.48 \\
\hline \multirow[t]{2}{*}{$\mathrm{R}_{05}$} & 2.768 & & 2.976 & & 1.920 & & \\
\hline & \multicolumn{7}{|c|}{ Dry matter yield, $\mathrm{t} \mathrm{ha}^{-1}$} \\
\hline Diploid, $\mathrm{n}=12$ & 6.23 & 8.53 & 1.43 & 23.52 & 2.05 & 21.58 & 9.71 \\
\hline Tetraploid, $n=6$ & 6.71 & 16.14 & 1.52 & 18.28 & 2.27 & 17.36 & 10.50 \\
\hline \multirow[t]{3}{*}{$\mathrm{R}_{05}$} & 0.642 & & 0.401 & & 0.481 & & \\
\hline & \multicolumn{7}{|l|}{2011} \\
\hline & \multicolumn{7}{|c|}{ Grass yield, $\mathrm{t} \mathrm{ha}^{-1}$} \\
\hline Diploid, $\mathrm{n}=12$ & 3.77 & 45.80 & 4.52 & 43.02 & 6.68 & 29.57 & 14.90 \\
\hline Tetraploid, $n=6$ & 6.18 & 39.11 & 6.00 & 42.35 & 8.00 & 19.82 & 20.38 \\
\hline \multirow[t]{2}{*}{$\mathrm{R}_{05}$} & 2.561 & & 2.730 & & 2.400 & & \\
\hline & \multicolumn{7}{|c|}{ Dry matter yield, t ha ${ }^{-1}$} \\
\hline Diploid, $\mathrm{n}=12$ & 0.92 & 23.63 & 0.85 & 29.67 & 1.38 & 25.82 & 3.15 \\
\hline Tetraploid, $\mathrm{n}=6$ & 1.35 & 21.85 & 1.05 & 34.62 & 1.68 & 11.89 & 4.08 \\
\hline $\mathrm{R}_{05}$ & 0.365 & & 0.426 & & 0.389 & & \\
\hline
\end{tabular}

*n, number of varieties and populations

2008-2009. The highest difference was found for the 2009 sowing year cycle when heavy damage by Sclerotinia trifoliorum and Fusarium spp. occurred in 2011. Forage and DM yields of diploid red clover genotypes were about $75 \%$ in 2010 and $25 \%$ in 2011. Forage and DM yields of tetraploid genotypes were about 70 and 30\%, respectively. Similar but slightly lower differences, also due to the same reason, were observed in fields sown in 2003 and harvested in 2004-2005. Fresh forage and DM yields of both diploid and tetraploid red clover genotypes were about 65 in the 2004 harvest year and 35\% in 2005. 2006 was much dryer than 2007 and forage yield was considerably higher in the wetter 2007. However, DM yield was almost the same for both years and both genotypes.

The average forage and DM yields were verey similar for diploid and tetraploid genotypes when averaged over all years. Of the annual harvest, the forage and DM yields of the $1^{\text {st }}$ cut were about $50 \%$, the yields of the $2^{\text {nd }}$ cut were about $30 \%$ and the yields of the $3^{\text {rd }}$ cut were about $20 \%$.

However, some considerable variation was observed among some years. The proportion yield of the first cut $\%$ for forage and DM were the most stable, and ranged from 43.5 to $50.1 \%$ for forage and from 45.9 to $55.6 \%$ for DM for diploids. For tetraploids, it ranged from 43.0 to $54.5 \%$ for forage yield and from 44.7 to $55.6 \%$ for DM yield. The relative yield $\%$ of the $2^{\text {nd }}$ cut differed more among years, ranging from 22.1 to $38.9 \%$ for forage yield and from 17.7 to $43.4 \%$ for DM yield for diploids, and from 23.3 to $40.2 \%$ and from 17.6 to $38.1 \%$, respectively, for tetraploids. The 
yield of the $3^{\text {rd }}$ cut was also highly variable. Relative forage and DM yield varied from 12.8 to $27.2 \%$ and from 10.8 to $28.2 \%$ for diploids, respectively. Tetraploid forage and DM yield varied from 14.3 to $26.8 \%$ and from 11.0 to $27.9 \%$, respectively.

Coefficients of variation showed that differences among genotypes were not high in years favourable for plant survival. CV tended to range from about 10 to $20 \%$ for the $1^{\text {st }}$ and $2^{\text {nd }}$ cuts among genotypes of both types. The $3^{\text {rd }}$ cut yields varied up to $30 \%$ in some cases. The most variable was crop sown in 2009, and for which CV exceeded $40 \%$ among genotypes in 2011.

The seed yields were very low over the period (Table 6). The seed yields of diploid genotypes were 58.0, 124.7, $217.0,41.9 \mathrm{~kg} \mathrm{ha}^{-1}$ with an average of $110.4 \mathrm{~kg} \mathrm{ha}^{-1}$. The seed yields of tetraploid genotypes were 161.8, 68.8, 120.0, $28.8 \mathrm{~kg} \mathrm{ha}^{-1}$ with an average $94.9 \mathrm{~kg} \mathrm{ha}^{-1}(2004,2006$, 2008, 2010 years, respectively). The average seed yield of the diploid population's was higher than that of tetraploid populations by $16.3 \%$. The highest negative impact on seed yield was due to wet weather, which promoted development of diseases on above-ground plant parts. CV among diploid genotypes varied from 33.3 to $60.3 \%$ in experimental years. Similar variation was observed among tetraploid genotypes: range from 18.8 to $70.6 \%$.

Table 6

RED CLOVER DIPLOID AND TETRAPLOID GENOTYPE'S SEED YIELDS IN 2004, 2006, 2008 AND 2010

\begin{tabular}{|c|c|c|c|c|c|}
\hline Sowing year & 2003 & 2005 & 2007 & 2009 & Average \\
\hline Harvest year & 2004 & 2006 & 2008 & 2010 & \\
\hline Diploid, seed yield kg ha ${ }^{-1}$ & 58.0 & 124.7 & 217.0 & 41.9 & 110.4 \\
\hline $\mathrm{CV}, \%$ & 37.91 & 33.29 & 52.50 & 60.26 & \\
\hline Tetraploid, seed yield $\mathrm{kg} \mathrm{ha}^{-1}$ & 161.8 & 68.8 & 120.0 & 28.8 & 94.9 \\
\hline $\mathrm{CV}, \%$ & 18.76 & 43.23 & 65.90 & 70.59 & \\
\hline $\mathrm{R}_{05}$ & 18.018 & 21.192 & 44.456 & 13.517 & 10.282 \\
\hline
\end{tabular}

2003: diploid $\mathrm{n}=12$, tetraploid $\mathrm{n}=6 ; 2005$ : diploid $\mathrm{n}=18$, tetraploid $\mathrm{n}=$ 11 ;

2007: diploid $\mathrm{n}=14$, tetraploid $\mathrm{n}=7 ;$ 2009: diploid $\mathrm{n}=12$, tetraploid $\mathrm{n}=6$

\section{DISCUSSION}

Traditionally, red clover is cut twice a year when it is at $50 \%$ bloom or greater. With this harvest system farmers end up cutting too late to obtain maximum forage quality. More recently, farmers have been cutting red clover three times during the summer to obtain higher quality forage. However, with a three-cut system, farmers are concerned that they may give up yield and persistence (Wiersma and Bolen 2000). In our investigation, a three cut system was used, exceptin in 2006 year. In 2006, forage was cut twice because of drought.

The variation of forage and DM yield showed that DM is a more reliable criterion for evaluation of yield of red clover genotypes. This was especially evidentc for tetraploids due to their higher content of water. Some investigations have shown that forage yield of tetraploid can be higher more than $50 \%$ in cases when DM yield is higher only by up to 10\% (Leto et al., 2004; Zuk-Golaszewska et al., 2010). Our results confirm this relationship, as forage yield of tetraploid genotypes was higher by $12.3 \%$, compared that of with diploid genotypes, while DM yield was higher by only by $6.5 \%$. The water demand for tetraploids is higher, as the yield is lower than for diplods in dry years (Graman, 1988). A similar but not as evident relationship was observed in our trials. DM yield of tetraploid red clover was lower in 2005 and 2008 when some water deficiency occurred. However, DM yield of tetraploid red clover was slightly higher in 2006 when severe water deficiency occurred due to drought and precipitation deficit in the previous year. The results of our study show that tetraploid red clover did not have a significant advantage over diploid red clover in DM yield under Lithuanian conditions. The main constraint of high and stable forage and DM yield for both ploidy types were fungal pathogens S. trifoliorum and Fusarium spp., which caused plant death during winter. Such a situation occurred in 2005 when the second year yield decreased twice compared to first year yield. An even more severe yield decrease (three times) occurred in 2011. The causal agent of clover rot, $S$. trifoliorum is economically one of the most important pathogens of young red clover stands in Europe and North America. Clover rot may completely destroy large patches in red clover fields during winter. Root rot, mainly caused by Fusarium spp. causes severe injuries in older red clover crops (Yli-Mattila et al., 2010). Svirskis and Juknevičius (2006) considered that new Lithuanian red clover cultivars have good disease resistance. However, severe decreases of yield in years favourable for pathogens showed that red clover of both types require directed improvement for disease resistance under Lithuanian conditions. Climate change has resulted in milder winters with shallow snow, which promotes plant infection by diseases causing root and crown rots, especially $S$. trifoliorum. The consequences of climate change weree seen from our study, when forage and DM yield decreased three times compared to first year yields in 2011. Therefore, disease evaluation and establishment of special fields should be one of priorities for successful red clover cultivar development. Red clover cultivars with improved disease resistance are characterized by high persistence. Such cultivars can be productive for three and even four years (Abberton and Marshall, 2005; Taylor, 2008; Hejduk, 2011). Many researchers have shown that visual evaluation of yield is effective and in many cases is highly correlates with conventional evaluation of forage yield. Visual evaluation is even more effective when individual plants are evaluated (Choo, 1984; Jaluvka et al., 2009; Riday, 2009; Lugic et al., 2010). Sowing of plants as separated individuals in fields should be utilized, considering the highly negative effect of diseases damaging all parts of plats under Lithuanian conditions. Sowing as plots should be established only after very comprehensive evaluation for disease resistance and other desirable traits. This evaluation scheme is in accordance with low to medium 
variation of tested genotypes by forage and DM yields that are highly affected by diseases, particularly considering the low general progress world-wide (Taylor, 2008) and not high genetic variability of grown cultivars (Campos de Quiroz and Ortega-Klose, 2001).

The variation in seed yield showed that production of diploid red clover seeds is less problematic. One of the reasons why tetraploids yield lower seed can be longer floral tube together with genetic peculiarities related to seed set (Taylor and Quesenberry, 1996). Under Lithuanian conditions, the only honey bee race 'Caucasian' is available as an efficient pollinator of red clover. The other honey bee races are inefficient pollinators due to a shorter tongue. The lower flower number per flower head also can negatively influence seed yield of tetraploids (Muntean, 2008). Seed yield of diploids was twice higher than that of tetraploids in three years of four. Seed weight was twice higher for tetraploids. Therefore, seed number of tetraploids was lower by four times. This indicates that seed set in tetraploids is very problematic. Decrease of plant number after winter should not highly negatively influence seed yield. Diseases damaging above ground parts of red clover is much more harmful for seed production than that for forage yield due to a much longer period of diseases development on seed crop. The high level of disease is very harmful to red clover under Lithuanian conditions. Seed yield of cultivars susceptible to many diseases can be lost totally in years favourable to diseases. In many cases these favourable conditions are due to rainy weather. These conditions also cause severe lodging of crops which in turn complicates harvesting the remaining seeds. It seems that only directed disease resistance breeding can help to improve seed yield of red clover. Visual evaluation of individually grown plants should allow selecting the most resistant plants possessing a complex of desirable traits also in the case of selection for forage yield.

\section{REFERENCES}

Abberton, M. T., Marshall, A. H. (2005). Progress in breeding perennial clovers for temperate agriculture. J. Agric. Sci., 143, 117-135.

Anonymous (2009). Rotklee. In: Bundessortenamt. Beschreibende Sortenliste (S. 89-94). Hannover (in German).

Black, A. D., Laidlaw, A. S., Moot, D. J., O'Kiely, P. (2009). Comparative growth and management of white and red clover. Irish J. Agr. Food Res., 48, 149-166.

Campos de Quiroz, H., Ortega-Klose, F. (2001) Genetic variability among elite red clover (Trifolium pratense L.) parents used in Chile as revealed by RAPD markers. Euphytica, 122, 61-67.

Choo, T. M. (1984). Association between growth habit and persistence in red clover. Euphytica, 33, 177-185.

Drobna, J. (2009). Yield and forage quality of Romanian red clover (Trifolium pratense L.) varieties studied in Slovakia. Not. Bot. Hort. Agrobot. Chuj., 37, 204-208.
Graman, J. (1988). The production ability and variety characteristics of selected diploid and tetraploid varieties of red clover under different agroecological conditions. Acta Sci., 32, 92-154.

Hejduk, S. (2011). Differences in persistence in red clover cultivars as an important trait for their use in permanent grassland. Grassland Sci. Eur., 16, $76-78$.

Helgadottir, A., Larsen, A., Marum, P., Fritsen, H., Lindvall, E., Miettinen, E. (2000). Prebreeding of red clover (Trifolium pratense L.) for northern areas. Acta Agric. Scand., Sect. B, Soil Plant Sci., 50, 187-190.

Jaluvka, L., Dostal, V., Meyer, V., Bayle, B., Lapage, F., Chloupek, O. (2009). Comparison of breeding methods for forage yield in red clover. Acta Univ. Agric. Silvicult. Mendelianae Brunensis, 57, 1-8.

Leto, J., Kneževic, M., Bošnjak, K., Macešic, D., Štafa, Z., Kozumplik, V. (2004). Yield and forage quality of red clover (Trifolium pratense L.) cultivars in the lowland and the mountain regions. Plant Soil Environ., 9, 391-396.

Lugic, Z., Radovic J., Sokolovic, D., Jectic, G., Milenkovic, J. (2010). Variability and correlative relations of important traits for red clover (Trifolium pratense L.) half sib progenies. In: Sustainable Use of Genetic Diversity in Forage and Turf Breeding (pp. 313-318). Huyghe, C. (Ed.). Dordrecht: Springer.

Marcinkevičienè, A., Bogužas, V. (2011). The effect of meteorological factors on the productivity of catch crops in sustainable and organic farming systems. Zemdirbyste-Agriculture, 98, 245-250.

Muntean, L. (2008) A comparative study of the variability of some morphological traits in a collection of diploid and tetraploid cultivars of red clover. In: Proceedings of the 43rd Croatian and 3rd International Symposium on Agriculture, 18-21 February 2008 (pp. 317-321). Opatija, Croatia.

Muntean, L., Savati, M. (2003). Phenotypic correlations between productivity elements of red clover (Trifolium pratense L.). J. Centr. Eur. Agric., 4, 185-190.

Onal, A. O. (2011). Biodiversity in red clover (Trifolium pratense L.) collected from Turkey. I: Morpho-agronomic properties. Afr. J. Biotechnol., 10, 14073-14079.

Riday, H. (2009). Correlations between visual biomass scores and forage yield in space planted red clover (Trifolium pratense L.) breeding nurseries. Euphytica, 170, 339-345.

Svirskis, A., Juknevičius, S. (2006). Breeding of red clover varieties for conventional and organic agriculture. Zemdirbyste-Agriculture, 93, 314-321.

Tavlas, A., Tan, M. (2009). Yields and quality of some red clover (Trifolium pratense L.) genotypes in crop improvement systems as livestock feed. Afr. J. Biotechnol., 7, 633-641.

Taylor, N. L. (2008). A century of clover breeding developments in the United States. Crop Sci., 48, 1-13.

Taylor, N. L., Quesenberry K. H. (1996). Red Clover Science. London: Kluwer Acad. Publ., 226 pp.

Wiersma, D., Bolen, J. (2000). Red Clover Harvest Management. http://webcache.googleusercontent.com/search?q=cache:2p2HtaIIWBcJ: www.uwex.edu/ces/crops/uwforage/RC_HarvMgmt.htm+red+clover+yields \&cd=1\&hl=lt\&ct=clnk\&gl=lt.

Yli-Mattila, T., Kalko, G., Hannukkala, A., Paavanen-Huhtala, S., Hakala, K. (2010). Prevalence, species composition, genetic variation and pathogenicity of clover rot (Sclerotinia trifoliorum) and Fusarium spp. in red clover in Finland. Eur. J. Plant Pathol., 146, 13-27.

Zuk-Golaszewska, K., Purwin, C., Pysera, B., Wierzewska, J., Golaszewski J. (2010). Yields and quality of green forage from red clover di- and tetraploid forms. J. Elementol., 15, 757-770.

Received 12 November 2012

\section{DIPLOĪDĀ UN TETRAPLOİDĀ SARKANĀ ĀBOLIN̦A RAŽAS STARPĪBAS LIETUVĀ}

Tetraploīdam sarkanam āboliṇam Lietuvas apstākḷıs nav lielāka sausnas raža, salīizinot ar diploīdām formām, bet kopumā zemāka sēklu raža. 